\title{
Productivity Analysis of Coffee Production Process with Objective Matrix (Omax) Method (The Case Study at PT. Perkebunan Kandangan, Pulosari Panggungsari, Madiun)
}

\author{
Ma'ruf Pambudi Nurwantara ${ }^{1}$, Panji Deoranto ${ }^{2}$, Mas'ud Effendi ${ }^{3}$ \\ 1.Agriculture Industrial Technology Department, Brawijaya University, Indonesia
}

\begin{abstract}
Production activities each company are expecting the creation of productivity. This research was aims to determine levels of total and partial productivity by using Objective Matrix and propose improvements. The study was conducted at Perkebunan Kandangan Pulosari Panggungsari plantations began from January to April 2015. The data gathered consist of secondary data and primary data. Elements analyzed the productivity of human, machine, wood fuel and diesel fuel. The results showed that the value of productivity was experiencing fluctuating, the value of total productivity in the processing of coffee by 6,660. Partial productivity value on the human element of 1,635 and 1,463 for labor, fuelwood amounted to 1,162, working hours standing to 0.894 generator engines and diesel fuel of 1.49. Proposed improvements that can be done by optimizing the number and performance of every element of productivity.
\end{abstract}

Keywords: Coffee, Improvements, Objective Matrix, Productivity.

Author Correspondence:

Ma'ruf Pambudi Nurwantara

Agriculture Industrial Technology Department, Brawijaya University, Indonesia

E-mail: makrufpambudinurwantara@yahoo.co.id

\section{Introduction}

Productivity is needed to measure production costs precisely and accurately. Productivity is defined as the ratio between the results of activity with the value of all the inputs used in doing the activity. The results of this measurement and evaluation will provide information to the company about the level of efficiency achieved by the company in conducting its activities; it becomes important that the company can improve the competitiveness of products produced in a competitive global market.

PT. Perkebunan Kandangan Pulosari Panggungsari is a private company engaged in agriculture. The results of this plantation company are not optimal because the amount of plantation from the company has not fulfilled the installed capacity of the machine. So the management strives to achieve the lowest cost in the production process. Analysis of productivity levels in the expected elements can minimize the costs incurred in production. Omax is a partial productivity measurement system developed to monitor productivity in each part company with the criteria of productivity by the existence of a part of the objective [1]. OMAX productivity measurement model is a measuring tool that has advantages where the management role in determining the weight accordance the degree of importance of each criterion within the company, so more objective and flexible in the measurements made. The weighted method that can be used as part of the Analytical Hierarchy Process (AHP) method to stakeholders, the principle that must be understood in solving problems using AHP technique are decomposition, comparative 
Productivity Analysis of Coffee Production Process with Objective Matrix (Omax) Method (The Case Study at PT. Perkebunan Kandangan, Pulosari Panggungsari, Madiun)

judgment, synthesis of priority, logical consistency, grouping and degree of relationship between the objects that are based on existing criteria [2].

The results of these measurements will get key elements that are important to be evaluated and proposed improvements in productivity of PT. Perkebunan Kandangan Pulosari, Panggungsari. The purpose of this research is to determine the partial productivity of the company by using Objective Matrix (OMAX) method. Determine total productivity by using Objective Matrix (OMAX) method and suggest productivity improvement to PT. Perkebunan Kandangan Pulosari, Panggungsari by providing productive value that must be done.

\section{Material and Methods}

Research conducted at PT. Perkebunan Kandangan Pulosari, Panggungsari located in Madiun. The study was conducted in January - May 2015. Data processing was conducted in Computational and System Analysis Laboratory, Department of Agricultural Industry Technology Universitas Brawijaya. The research flow is a preliminary survey of company's condition and problems, field review and literature study, selection of productivity criteria, data collection using interview method, questionnaire, documentation. The next step is to analyze the data using the OMAX method with the stages of determining the performance of each criteria, determining the average value achieved during this (level 3 ), determining the productivity targets (level 10), determining the lowest score (level 0), filling the remaining level of matrices (levels 1-2 and 4-9), determining the score, weight and value and determining the indicators and evaluating the productivity by analyzing the scores achieved by the partial productivity of each criterion. Partial productivity results are used to evaluate total productivity by looking at the productivity index values that have been achieved each month. The results of the productivity evaluation will be used for identification of problems that occur in the company with the model diagram of causation (fishbone) in Figure 1. cause diagram can describe the condition of productivity of the company, so it can efficiently provide suggestions for improvement. The last step is the conclusion and recommendations that can be taken into consideration by the company to increase productivity by the company.

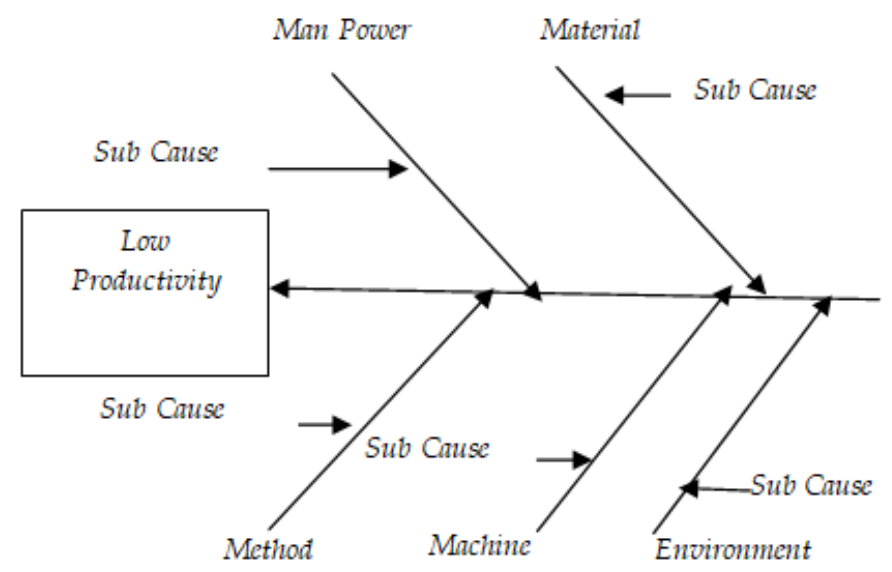

Figure 1

Fishbone Diagram 


\section{Results and Discussion}

\subsection{Production process}

Production process conducted at PT. Kandangan Plantation, Pulosari Panggungsari is a factory that processes coffee logs from its garden with Robusta and Arabica Coffee. The processing unit was divided into several stations that have different functions and objectives. The production process only uses Wet Process. Wet Process is a coffee production process that uses water as the auxiliary process. The type of coffee used in this production has a reddish-brown (half-baked) and red (mature) color.

\subsection{Selection of Productivity Criteria}

Selection of productivity criteria to be measured is criterion I. Criterion I is productivity of raw material usage; criterion II is productivity of labor usage; criterion III is productivity of wood fuel usage, criterion IV is productivity of working hour machine generator, criterion V is productivity solar used.

\subsection{Data processing}

The following data of PT Perkebunan Kandangan Pulosari Panggungsari shown in Table 1. Starting from the period of June 2011 to September 2014 with representatives from period 1 to 16. Table 1 shows that the number of raw coffee products has fluctuated, this is directly affected by the raw materials that experienced fluctuation, the amount of fluctuating raw materials influenced by the result of the garden due to land conditions that can not be maintained the consistency such as rainfall, soil fertility, and wind intensity. Apart from these external factors, the internal factors that affect the amount of coffee are the age of the coffee plant. Coffee crops in the company were mostly residuals from plants in 1970.

Table 1

Use of Input and Output

\begin{tabular}{ccccccc}
\hline Period & $\begin{array}{c}\text { (Output) } \\
(\mathbf{K g})\end{array}$ & $\begin{array}{c}\text { Criteria } \\
(\mathbf{I})\end{array}$ & $\begin{array}{c}\text { Criteria } \\
(\mathbf{I I})\end{array}$ & $\begin{array}{c}\text { Criteria } \\
(\text { III) }\end{array}$ & $\begin{array}{c}\text { Criteria } \\
(\text { IV) }\end{array}$ & $\begin{array}{c}\text { Criteria } \\
(\mathbf{V})\end{array}$ \\
\hline 1 & 344.440 & $1,903.000$ & 5.000 & 4.880 & 24.000 & 63.100 \\
2 & $2,129.470$ & $11,765.000$ & 5.000 & 30.200 & 72.000 & 390.000 \\
3 & $3,833.220$ & $21,178.000$ & 5.000 & 54.360 & 120.000 & 702.100 \\
4 & $2,146.300$ & $11,858.000$ & 5.000 & 30.440 & 72.000 & 393.100 \\
5 & 179.300 & $1,100.000$ & 5.000 & 2.690 & 24.000 & 34.700 \\
6 & $4,688.695$ & $28,765.000$ & 5.000 & 70.230 & 144.000 & 907.200 \\
7 & $7,527.014$ & $46,178.000$ & 5.000 & 112.750 & 240.000 & $1,456.400$ \\
8 & $2,019.896$ & $12,392.000$ & 5.000 & 30.260 & 72.000 & 390.800 \\
9 & 436.760 & $2,440.000$ & 5.000 & 6.060 & 24.000 & 78.300 \\
10 & $8,113.712$ & $45,328.000$ & 5.000 & 112.550 & 240.000 & $1,453.800$ \\
11 & $2,250.925$ & $12,575.000$ & 5.000 & 31.220 & 72.000 & 403.300 \\
12 & $8,370.756$ & $46,764.000$ & 5.000 & 116.120 & 240.000 & $1,499.900$ \\
13 & $1,710.910$ & $10,184.000$ & 5.000 & 25.740 & 48.000 & 332.500 \\
14 & $1,714.100$ & $10,203.000$ & 5.000 & 25.790 & 72.000 & 333.100 \\
15 & $2,501.860$ & $14,892.000$ & 5.000 & 37.640 & 72.000 & 486.200 \\
16 & $3,689.620$ & $21,962.000$ & 5.000 & 55.510 & 120.000 & 717.100 \\
\hline Average & & $18,717.938$ & 5.000 & 46.653 & 103.500 & 602.600 \\
\hline
\end{tabular}

Source: Secondary Data Processed (2015) 
Productivity Analysis of Coffee Production Process with Objective Matrix (Omax) Method (The Case Study at PT. Perkebunan Kandangan, Pulosari Panggungsari, Madiun)

Table 2

Performance Value of Productivity Criteria

\begin{tabular}{cccccc}
\hline Period & $\begin{array}{c}\text { (Output) } \\
\text { (Kg) }\end{array}$ & $\begin{array}{c}\text { Criteria } \\
\text { (I) }\end{array}$ & $\begin{array}{c}\text { Criteria } \\
\text { (II) }\end{array}$ & $\begin{array}{c}\text { Criteria } \\
\text { (III) }\end{array}$ & $\begin{array}{c}\text { Criteria } \\
\text { (IV) }\end{array}$ \\
\hline 1 & 0.181 & 68.888 & 70.582 & 14.352 & 5.459 \\
2 & 0.181 & 425.894 & 70.512 & 29.576 & 5.460 \\
3 & 0.181 & 766.644 & 70.515 & 31.944 & 5.460 \\
4 & 0.181 & 429.260 & 70.509 & 29.810 & 5.460 \\
5 & 0.163 & 35.860 & 66.654 & 7.471 & 5.167 \\
6 & 0.163 & 937.739 & 66.762 & 32.560 & 5.168 \\
7 & 0.163 & $1,505.403$ & 66.758 & 31.363 & 5.168 \\
8 & 0.163 & 403.979 & 66.751 & 28.054 & 5.169 \\
9 & 0.179 & 87.352 & 72.073 & 18.198 & 5.578 \\
10 & 0.179 & $1,622.742$ & 72.090 & 33.807 & 5.581 \\
11 & 0.179 & 450,185 & 72.099 & 31.263 & 5.581 \\
12 & 0.179 & $1,674.151$ & 72.087 & 34.878 & 5.581 \\
13 & 0.168 & 342.182 & 66.469 & 35.644 & 5.146 \\
14 & 0.168 & 342.820 & 66.464 & 23.807 & 5.146 \\
15 & 0.168 & 500.372 & 66.468 & 34.748 & 5.146 \\
16 & 0.168 & 737.924 & 66.468 & 30.747 & 5.145 \\
\hline Average & 0.173 & 645.712 & 68.954 & 28.014 & 5.338 \\
\hline
\end{tabular}

Source: Secondary Data Processed (2015)

\subsection{Partial Productivity and Value Evaluation (Score)}

The productivity measurement results evaluated on each of these criteria are:

\section{Raw Material Criteria}

Changes in productivity in the use of raw materials have the level of productivity interest to the productivity of the company with an interest level of 33.6\%. The criterion of the raw material of highest achievement score occurred in period 1-4 (in 2011) and period 9-12 (in 2013) with score 5 with partial productivity value equal to 1.68 , while achievement of lowest score happened in period 5-8 with score 1 with a partial productivity value of 0.336 . It shows that the company has not been able to utilize the use of raw materials that are owned optimally because the raw materials have not shown the achievement of the score 10. The not optimal productivity of the raw material s used can be caused by the raw material conditions are less good concerning quality and processing is not smooth.

\section{Criteria for Labor}

Changes in productivity in the use of labor have a level of productivity interest to the productivity of company with an interest level of $23.6 \%$. Based on the calculation of the productivity score achieved by the company on this criterion is fluctuating with the highest productivity value occurred in period 7 (July 2012), period 10 (July 2013), period 12 (September 2013), with a score of 10 and a par value of 2.38. While the lowest partial value occurs in the period 1 (June 2011), the period 5 (June 2012), the period 9 (June 2013) with a value of 0. It shows that the company has not been able to maintain consistency well because it looks up and down. The inability of the company to optimize the productivity of the company can be caused by the lack of skilled labor and the number of employees who are not suitable to process raw materials. This is in accordance with Ramadan (2013) which states that work productivity is a fundamental reference for the company in determining the wages of its 
Productivity Analysis of Coffee Production Process with Objective Matrix (Omax) Method (The Case Study at PT. Perkebunan Kandangan, Pulosari Panggungsari, Madiun)

workforce. Increasing the productivity of human factors is a strategic objective because the increase in other factors of production is highly dependent on the ability of human laborers to utilize it.

\section{The criterion of Wood Fuel}

Changes in productivity in the use of wood fuel have a level of productivity interest to the productivity of company with an interest level of $16.7 \%$. Based on the calculation of the highest achievement occurred in the period 9-12 (in 2013) with a score of 7 with a par value of 1.169. While the low achievement in the period 5-8 (in 2012), the period 13-16 (in 2014) with a score of 1 with a par value of 0.167 . This achievement may be due to several factors such as in the use of wood fuel needed in less efficient production processes, dry or wet wood fuel conditions resulting in different heat, and the type of wood used that affects the resulting heat resistance.

\section{Criteria Working Hours Generator Machine.}

Changes in productivity in working hours generator engines also affect the productivity changes with the importance of $15.7 \%$. Based on the calculation of productivity on the criteria of machine work hours the generator scores highest value occurred in September 2013, June 2014, August 2014 with a score of 6 each with a par value of 0.942 , and the lowest occurred in June 2012 with a score of 0 with a par value of 0 . This inconsistency may occur by factors such as supply delays, unmet machine capacity, damage or shutdown.

\section{Solar Fuel Criteria}

Changes in productivity in diesel fuel also affect the productivity changes achieved by PT. Plantation Kandangan Pulosari Panggungsari although with the importance of $10.2 \%$. Based on company productivity calculation ever reach the highest performance that occurred in the period 9-12 (2013) with a score of achievement of 10 with a partial value of 0.612 . But the achievement cannot be maintained by the company. While the lowest achievement in 2014 June - September with a score of 1 with a par value of 0.102 . This score is caused due to the inaccuracy in the use of diesel fuel required in the production process.

\section{Total Productivity Evaluation}

Total productivity evaluation was done by looking at the value of productivity index on performance indicator in OMAX matrix. The magnitude of the total production value can be seen in Figure 2 and the increase and decrease can be seen in Figure 3.

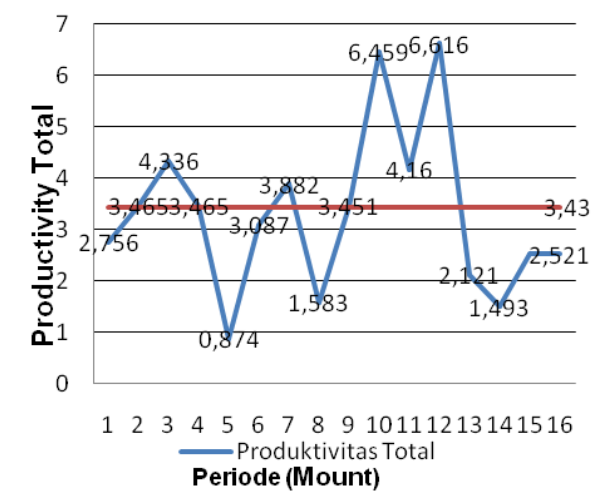

Figure 2. Total Productivity Graph

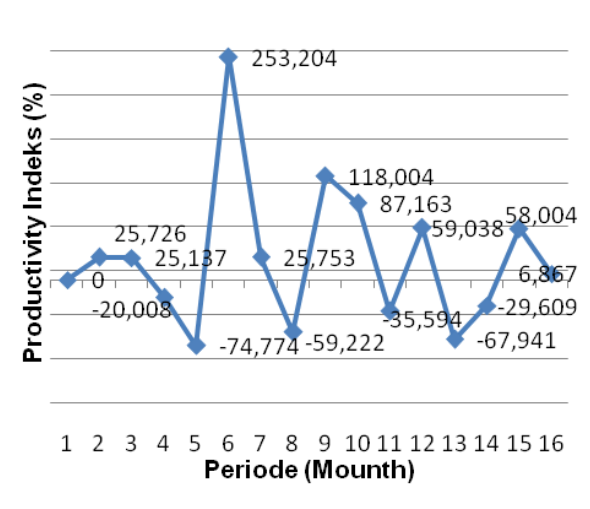

Figure 3. Indeks Productivity Graph 


\section{Total Productivity Graph}

The graph of the total productivity index value shown in Figure 2. shows that the graph fluctuates, depending on the productivity value achieved by the company during that period. Based on the average total productivity of 3.43 , where fluctuations occur so there is still a value of total productivity index that is below standard value. Figure 3. shows that in period 4 (September 2011) is the sharpest index decline with the productivity index of $-76.11 \%$ with productivity value 3,465 , this decrease because score value on labor usage has score 1. Period 6 (July 2012) there is an increase in the highest productivity indication of $253.204 \%$ with a value of 3.087 with a score of 5 . Changes in productivity index due to the harvest season that affects the number of raw materials processed, with the same time and amount of fuel so that the capacity in production is not constant.

The graph of the total productivity index value shown in Figure 2. Show that the graph fluctuates, depending on the productivity value achieved by the company during that period. Based on the average total productivity of 3.43 , where fluctuations occur so there is still a value of productivity index that is below standard value. Figure 3. shows that in period 4 (September 2011) is the sharpest index decline with the productivity index of $-76.11 \%$ with productivity value 3,465 , this decrease because score value on labor usage has score 1. Period 6 (July 2012) there is an increase in the highest productivity indication of $253.204 \%$ with a value of 3.087 with a score of 5 . Changes in productivity index due to the harvest season that affects the number of raw materials processed, with the same time and amount of fuel so that the capacity in production is not constant.

\section{Proposed Productivity Improvement}

Improvements are made based on the achievement of the last period of productivity, in June of 2014 as proposed improvements are proposed to improve productivity in subsequent processing periods.

The formula used is: Number of last period output(kg)

Thus obtained the proposed data used for June 2015 in Table 3.

Table 3

Proposed Productivity Improvement

\begin{tabular}{cccc}
\hline Criteria & Value of the Last Period & Number of Proposed Improvements & Waste \\
\hline Criteria I (kg) & $21,962.000$ & $18,921.128$ & $3,040.871$ \\
Criteria II (HOK) & 5 & 2 & 3 \\
Criteria III (m3) & 55.510 & 49.999 & 5.511 \\
Criteria IV (Jam) & 120.000 & 84.527 & 35.472 \\
Criteria V (Liter) & 717.100 & 667.805 & 49.295 \\
\hline
\end{tabular}

Source: Secondary Data Processed (2015)

Proposed improvements include:

\section{Proposed Raw Material Improvement}

Existing productivity criteria influence the achievement of optimal productivity. This can be achieved by reducing the causes of factors that lead to inefficient use of raw materials. Repairs are done by efficient use of coffee bean until it can achieve the value of productivity with a score of 10 . Based on these calculations, to produce coffee $3,689.620 \mathrm{~kg}$ per month required $18,921.128 \mathrm{~kg}$ of coffee bean. 
Productivity Analysis of Coffee Production Process with Objective Matrix (Omax) Method (The Case Study at PT. Perkebunan Kandangan, Pulosari Panggungsari, Madiun)

Initial condition in September 2014, the company uses the coffee raw material as much as $21,962.000 \mathrm{~kg}$ so with such raw materials that waste of $3,040.720 \mathrm{~kg}$ of optimal use of raw materials. Based on the diagram fishbone in Figure 1. waste that occurs in the company, among others, caused by the quality of raw materials that are not appropriate, raw materials are defective because of insect contamination. Processing that is not appropriate to cause damage to raw materials is also a factor of waste. Indirectly the limitations of skill and skill of employees due to lack of training obtained and less strict supervision can also lead to waste of raw materials usage. Besides, the number of raw materials to be produced must be following the production capacity for the production process to run smoothly, the supply of raw materials must be able to meet production needs. Too much supply of raw materials will add capital requirements. However, if too little, the need for raw materials for the production process is disrupted [3].

\section{Labor Productivity}

Improvement of productivity in the use of labor is the efficient use of labor to achieve the value of productivity with a score of 10 by calculating the efficient level of labor required. Based on these calculations than to produce a product of $3,689.92 \mathrm{~kg}$ per month needed two labors. The crew conditions in September 2014 employed five workers, resulting in a wasted workforce of 3 workers. The proposal is an efficient level achieved to improve labor productivity.

Achievement of a score that has not been optimal is possible because the company has not been concerned about the skills and education level of its workforce so that the workforce lacks understanding of the importance of productivity. Other factors that may affect our environmental factors, methods, the inconvenience of the work environment, internal problems between workers and improper facility layout, the determination of the wrong amount of labor, the lack of supervision from the supervisor, and not yet fully automated machines are also one cause.

Proposed improvements that can be made is to conduct a further assessment of the skills of each worker to determine which workers will continue to use. Implementation of job training to workers to improve workers' ability and understanding of workers in the production process. In addition to job training, can also be done non-job training programs such as motivational seminars and worker commitment to job responsibilities. That motivation theory says that one's productivity can be determined by the "mental virus" that is in him. The mental virus is a condition of the soul that encourages a person to be able to achieve maximum achievement [4].

\section{The productivity of Wood Fuel}

Based on these calculations, to produce a product of 3,689.62 $\mathrm{Kg}$ per month required $49.999 \mathrm{~m} 3$ wood fuel. Initial conditions in September 2014 need $55,510 \mathrm{~m}^{3}$ of wood fuel so that wood fuel is 5,511 $\mathrm{m}^{3}$. The continuous waste of fuel causes the company to lose.

Proposed improvements that can be given are by choosing the appropriate type of firewood for the needs of the dryer fuel. The type of firewood used is very influential on wood resistance and hightemperature achievement. The longer the achievement of high temperatures the more wood is used. However, the effect of firewood cost must also be taken into account because good firewood types also have relatively high prices that can affect the level of productivity of wood fuel consumption concerning processing costs. 
Productivity Analysis of Coffee Production Process with Objective Matrix (Omax) Method (The Case Study at PT. Perkebunan Kandangan, Pulosari Panggungsari, Madiun)

Awareness of manpower in fuel economy becomes one factor in increasing productivity of wood fuel usage. The ability of employees and their skills to influence accuracy in the use of wood fuel, also, oversight of the foreman is also required in every process of fuel use during processing. Besides, coffee raw materials that have the different water content in each process require precision in calculating the amount of firewood used.

\section{Productivity Hours Work Generator}

Based on the calculation to produce a product of 3,689.62 Kg per month required 84,527 hours. Initial conditions in September 2014 the company requires 120 hours, so the working hour's generator experience waste of 35,473 hours. The waste of generator working time resulted in a rapidly damaged generator.

Efforts made to increase the productivity of working hours generator machine is to motivate labor and close supervision of the workers concerned to utilize the working hour's generator engine efficiently. The reduced operational disturbance that occurs in the processing machine by performing maintenance and use of standard setting on the use of processing machine. The damage to the equipment can hamper the growth of productivity in the company, and also with the downtime that occurs on one machine then automatically the production process will be disrupted until the machine operates again [5].

\section{Solar Fuel Productivity}

Based on these calculations, to produce a product of 3,689.620 kg per month required 667,805 liters. Initial conditions in September 2014 companies require 717,100 liters, so diesel fuel waste of 49.295 liters. Wasting the amount of diesel fuel continuously results in losses for the company.

Efforts that can be made to increase productivity in the use of diesel fuel is to efficiently energy by applying cooperation between labor to improve each other. Supervision of labor in the production process as efficiently as possible. Supervision must be able to give understanding to the workers in the effort of maximum utilization. The inventory control is as an activity to determine the level and composition of the supply of parts, raw materials and products or products so that the company can protect the smoothness of production and sales and expenditure needs effectively and efficiently [6].

\section{Conclusion}

The value of productivity achieved by PT. Perkebunan Kandangan, Pulosari Panggungsari has fluctuated. The highest value of the level of partial productivity achieved by the company on raw material criterion occurs in the period 9-12 (2013) with a par value of 1.68. Labor criteria occurred in period 7 (August 2012), period 10 (July 2013) and period 12 (September 2013) with a par value of 2.38. Wood fuel criteria in the period of 9-12 (2013) with a par value of 1.002. Criteria of working hours of generator machine in the period of 12 (September 2013), period 13 (June 2014), period 15 (August 2014) with a par value of 0.942. Criteria for diesel fuel in the period of 9-12 (in 2013) partial value of 0.612 .

Meanwhile, the highest total production value achieved by the company is in the measurement period 12 (September 2013) of 6.616 and the lowest measurement value 5 (June 2012) of 0.874. In the 16 measurement periods, total productivity decreases occurred in the period September 2011, September 2012, August 2013, June 2014, July 2014. 
Productivity Analysis of Coffee Production Process with Objective Matrix (Omax) Method (The Case Study at PT. Perkebunan Kandangan, Pulosari Panggungsari, Madiun)

Achieving optimum productivity value on each criterion can be achieved by improving quality and yield on raw material (coffee bean), improving skill and motivation of labor, accurate use of wood fuel, improving engine performance with routine engine maintenance, diesel fuel efficiency and prioritize the achievement of the company's production targets. Improvements in supervisory systems by the leaders.

\section{Acknowledgement}

Our deep and sincere gratitude is given to God for giving us health and an opportunity to finish this writing. Thank you very much to our colleagues who have helped in the research and completed this writing.

\section{References}

[1] Yosan, B., Kholil M., \& Soraya, W. (2016) Increasing Productivity with Objective Matrix Method Case Study on Building Maintenance Management PIO PT. XXX. Proceeding of 9th International Seminar on Industrial Engineering and Management

[2] Udayana, I.G.B. (2015). Model Development Industrial Cluster Coffee Arabica in The District Bangli, Province of Bali. International Journal on Advanced Science, Engineering and Information Technology, 5 (4), 294-297.

[3] Aziz, S.R. (2012). Analisis Efisiensi Persediaan Bahan Baku Industri Abon Lele Karmina di Kabupaten Boyolali. E-Jurnal Agrista Vol. 4 No.1

[4] Nenny, A. (2011). Pengaruh Kemampuan dan Motivasi Terhadap Kinerja Pegawai Pada Sekolah Seni Indonesia (STSI) Bandung. Jurnal Penelitian Pendidikan Vol. 12 No. 2

[5] Taufiq, M.R.I. (2013). Analisis Produktivitas Bagian Pengolahan Susu Pasteurisasi Menggunakan Metode Objective Matrix (OMAX) (Studi Kasus Koperasi Susu SAE Pujon). Fakultas Teknologi Pertanian Universitas Brawijaya. Malang.

[6] Edi, S., Eman, S., \& Ria, R. (2012) . Analisis Pengendalian Persediaan Bahan Baku pada PT. NT Piston Ring Indonesia. Jurnal Manajemen Vol. 10 No. 1 